\title{
Paki Harrison: Tohunga Whakairo. The Story of a Master Carver by Ranginui Walker'
}

\author{
Review by Carin Wilson
}

The great pleasure of reading one of Rangi's books derives from his uncompromising approach, which firmly contextualises the content in a Māori point of view. Chapter headings and subheadings, events and places, narrative detail they all transport the reader to a place where we cannot but engage with the Māori world. Slowly, carefully, we track in this book the young Pakāriki Harrison through the stuff of biography: his whakapapa, childhood in Ruatoria, early influences (especially those of his indulgent grandmother Materoa, matriarch of Ngati Porou), and his training as a schoolteacher, which gave him insight into the lives of less privileged communities. There are hints in these early pages of what is to come: from adventures while felling and sawing timbers with his father Harangi, to an account of a pivotal phase during Paki's teacher training at Palmerston North: Pine Taiapa came to visit Paki in the evenings to tutor him and carefully encourage his interest. Yet it is easy to see that destiny was made in these formative years in a kind of old-fashioned Māori way, in which the inevitable forces of whakapapa swing into action. We watch how Paki's life was being carefully moulded, to equip him with the tools needed for what was to unfold. Nevertheless, his was not to be the tapu life of the tohunga of the traditional world. ${ }^{2}$ Paki revels in being the occasional rabble-rouser, Paki falls in love and marries Hinemoa, Paki buys a Ford Zephyr, Paki carves in the presence of his grand-daughter.

Despite its focus on the life of this carver, the book provides a fascinating insight into the massive shifts in Māori society over the last few generations. Today, we see how the functional values of tohungatanga have become reframed in Aotearoa/New Zealand's hybrid society of Polynesian and Occidental practices. The Ngata method, whereby students were schooled in compositional and tool skills alone, did not resonate with Paki, in spite of his Ngāti Porou heritage. ${ }^{3}$ This carver challenged conventions about value, establishing models for estimating time-related costs in a world where scant attention was paid to the passage of time; he railed against the sometimes inadequate evidence of skills transfer in the training of his contemporaries; he pioneered the development of unit standards, ${ }^{4}$ where some would have deemed it impossible to establish a standard on artistry. Pakāriki Harrison was unquestionably a Master of Whakairo, but it is clear that an expansive vision led him to master many other skills during his lifetime.

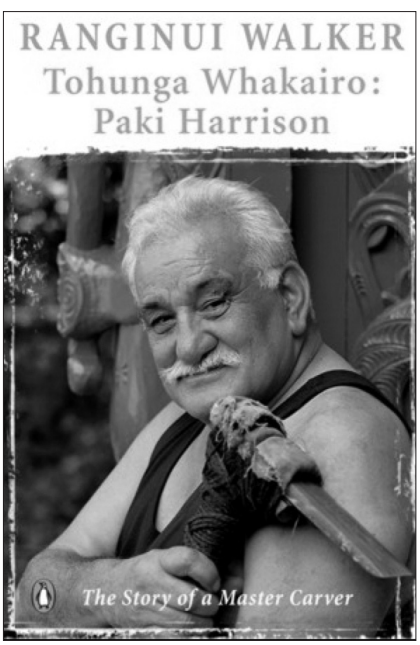

I. Ranginui Walker (2009) Paki Harrison: Tohunga Whakairo. The Story of a Master Carver. Auckland: Penguin Books (New Zealand), ISBN: 978-0I43010067.

2. For Māori terms, see Glossary.

3. Sir Apirana Turupa Ngata (1874-1950) was a Māori leader, politician, statesman, and scholar. Ngata was intensely involved in the revitalisation of Māori culture. He placed great store in carving and encouraged the building of carved memorials or meeting houses.

4. Unit Standards were introduced by the New Zealand Qualification Authority in the 1990s as part of the National Qualifications Framework, with the intention of standardising courses offered by public and private educational providers. 
Rangi Walker recognises that it would be futile to try and chronicle the majesty of his body of work (such is the importance of the direct sensory experience which massive creative works like wharenui have on our neurology). Instead, he seizes the opportunity to give us an insight into ways in which the carver handles the responsibility of managing his own creativity. This involves, for instance, finding a way through a prescriptive narrative, embodying tribal styles, whakapapa and formal decorative elements (such as maihi, tāhuhu, poutokomanawa, kowhaiwhai and tukutuku, to name a few). For those who want to understand Māori architecture at a level that calls us to probe beyond stunning visual images, the book offers some substantial material detail in karakia, waiata, and primary gestures in the carver's repertoire. Accepting the range of Paki's work as given, some of the most intriguing passages in this book deal with attempts by patrons or commissioning committees to challenge his authority as an artist and manage, or even control, his artistic input. We are to discover how the weight of the responsibility of unveiling and arranging a narrative, which reveals characters and events spanning hundreds of years, is handled. Time after time, project upon project, we are exposed to the spectacle of interlopers who would seek to borrow or trade on the mana of the work of the carver. We watch the frenzy of positioning, swelling up around the time of the house's opening. This frenzy often manifests in the account as unseemly posturing and shameless borrowing, out of highly questionable motives. In the nature of things, these actions were hardly minor skirmishes, but rather engagements on the scale of pitched battles, where sustained assaults on the authority of the carver were mounted. It becomes increasingly clear over the course of the narration that the work of the tohunga of whakairo is still so influential that insubstantial ambitions will seek to enlarge their own stature by hitching a ride in the slipstream. Some of these encounters would have tested the mettle of the strongest of characters, and it is a measure of Paki's early upbringing that he was able to face these challenges with forthright authority and character. Ultimately, Rangi Walker guides us skilfully through Paki's world beyond the mallet and chisel, through a world of training schemes, degree-level tertiary programmes, the development of the Toi Iho mark and the odd squabble over land at Harataunga. More importantly, he leads us to understand and respect the compelling values of whānau and kāinga as underlying forces in this odyssey. Paki's partnership with Hinemoa proved to be as much evident in their artistic collaborations as in their marriage. Later, their children also became involved in their projects. While he was working on Tanenui-a-Rangi at the University of Auckland, Paki began taking work across to the studio workshop he had built at Harataunga in Kennedy Bay on the Coromandel Peninsula. This was to set in train a pattern of commuting from project to the home kāinga, which would continue until his work in this world was done.

I was eager to read this biography, and my anticipation has been well rewarded. A body of work including 10 houses and numerous individual commissions is a remarkable achievement in one lifetime. The fertile mix of skill, intellect and unending appetite for knowledge on the part of both biographer and subject have given us a great story. 


\section{Glossary ${ }^{5}$}

\begin{tabular}{ll} 
kāinga & abode \\
\hline karakia & invocation, prayer \\
\hline kowhaiwhai & pattern used on rafters of wharenui \\
\hline maihi & gable \\
\hline mana & dignity, control, power \\
\hline poutokomanawa & $\begin{array}{l}\text { central heart post of the meeting house, supporting } \\
\text { the tāhuhu }\end{array}$ \\
\hline tāhuhu & ridgepole, ancestry \\
\hline tapu & sacred \\
\hline tohunga & craftsman, expert \\
\hline tohungatanga & craft, expertise \\
\hline tukutuku & lattice-work \\
\hline waiata & chant, song \\
\hline whakairo & carving \\
\hline whakapapa & genealogy \\
\hline whānau & family, birth \\
\hline wharenui & meeting house
\end{tabular}

5. Unless stated otherwise, translations are adopted from H.M. Ngata, EnglishMaori Dictionary at http://www.learningmedia.co.nz/nz/online/ngata

6. http://www.tepapa.govt.nz/education/ onlineresources/sgr/pages/rongomaraeroa.aspx 